Section Editor

Mitchell S.V. Elkind,

MD, MS

Teaching NeuroImages:

\title{
Diffusion tensor tractography of cortico-ponto-cerebellar pathways in Rasmussen encephalitis
}

Roberto Michelucci, MD, A 34-year-old man developed since age 18 years epiPhD*

Elena Pasini, MD*

Federica Anna Marliani, MD*

Luigi Cirillo, MD*

Correspondence to

Dr. Pasini:

elenapasini123@gmail.com

lepsia partialis continua followed over the years by progressive ataxic hemiparesis involving the left side (figure 1).

Structural cerebral abnormalities, mitochondrial diseases, and known autoimmune disorders were excluded. ${ }^{1}$ Cerebral MRI showed progressive right cerebral and crossed left cerebellar hemiatrophy (figure 2, A and B).

Tractography of cortico-ponto-cerebellar (CPC) pathways $^{2}$ (figure 2, C and D) demonstrated marked involvement of the right tract, suggesting that a dying-back mechanism of efferent CPC fibers may cause crossed cerebellar atrophy. We infer that crossed cerebellar atrophy is a distinctive feature of long-term Rasmussen encephalitis evolution.

\section{AUTHOR CONTRIBUTIONS}

Roberto Michelucci: drafting/revising the manuscript, study concept or design, analysis or interpretation of data, accepts responsibility for conduct of research and final approval, study supervision. Elena Pasini: drafting/ revising the manuscript, study concept or design, analysis or interpretation of data, accepts responsibility for conduct of research and final approval, study supervision. Federica Anna Marliani: study concept or design, accepts responsibility for conduct of research and final approval, acquisition of data. Luigi Cirillo: drafting/revising the manuscript, accepts responsibility for conduct of research and final approval, neuroradiologic evaluation.

\section{STUDY FUNDING}

No targeted funding reported.

\section{DISCLOSURE}

The authors report no disclosures relevant to the manuscript. Go to Neurology.org for full disclosures.

\section{REFERENCES}

1. Varadkar S, Bien CG, Kruse CA, et al. Rasmussen's encephalitis: clinical features, pathobiology, and treatment advances. Lancet Neurol 2014;13:195-205.

2. Kamali A, Kramer LA, Frye RE, Butler IJ, Hasan KM. Diffusion tensor tractography of the human brain corticoponto-cerebellar pathways: a quantitative preliminary study. J Magn Reson Imaging 2010;32:809-817.

Figure 1 Clinical features over a 22-year history

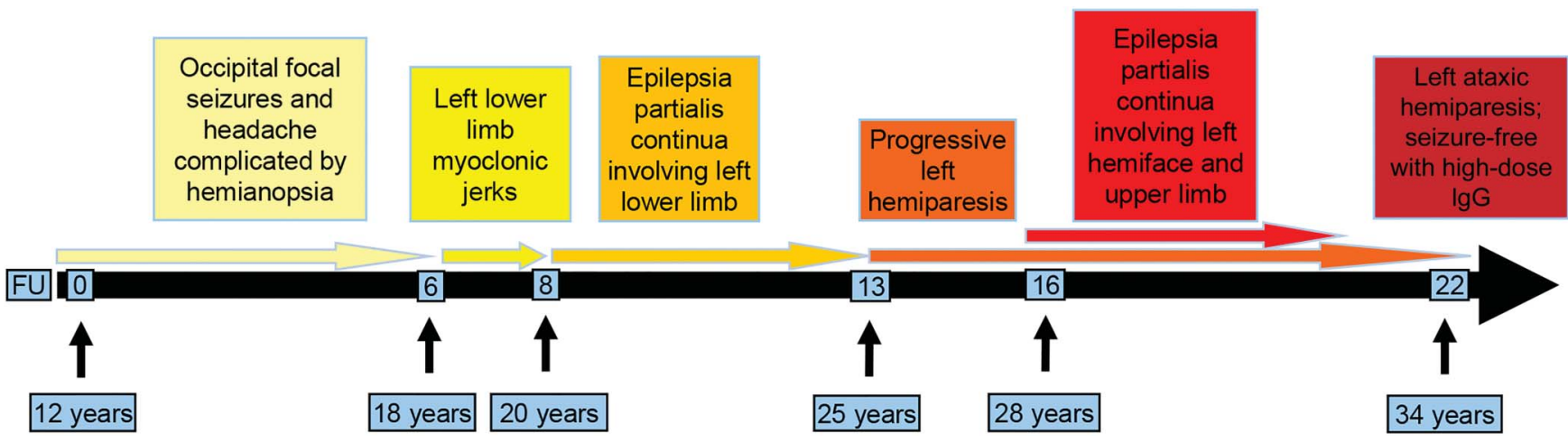

$\lg \mathrm{G}=$ immunoglobulin $\mathrm{G}$.

Download teaching slides: Neurology.org
*These authors contributed equally to this work.

From IRCCS-Institute of Neurological Sciences, Units of Neurology (R.M.) and Neuroradiology (F.A.M., L.C.), and the Department of Biological and Neuromotor Sciences (E.P.), Bellaria Hospital, Bologna; and DIMES (L.C.), Department of Specialty, Diagnostic and Experimental Medicine, University of Bologna, Italy. 


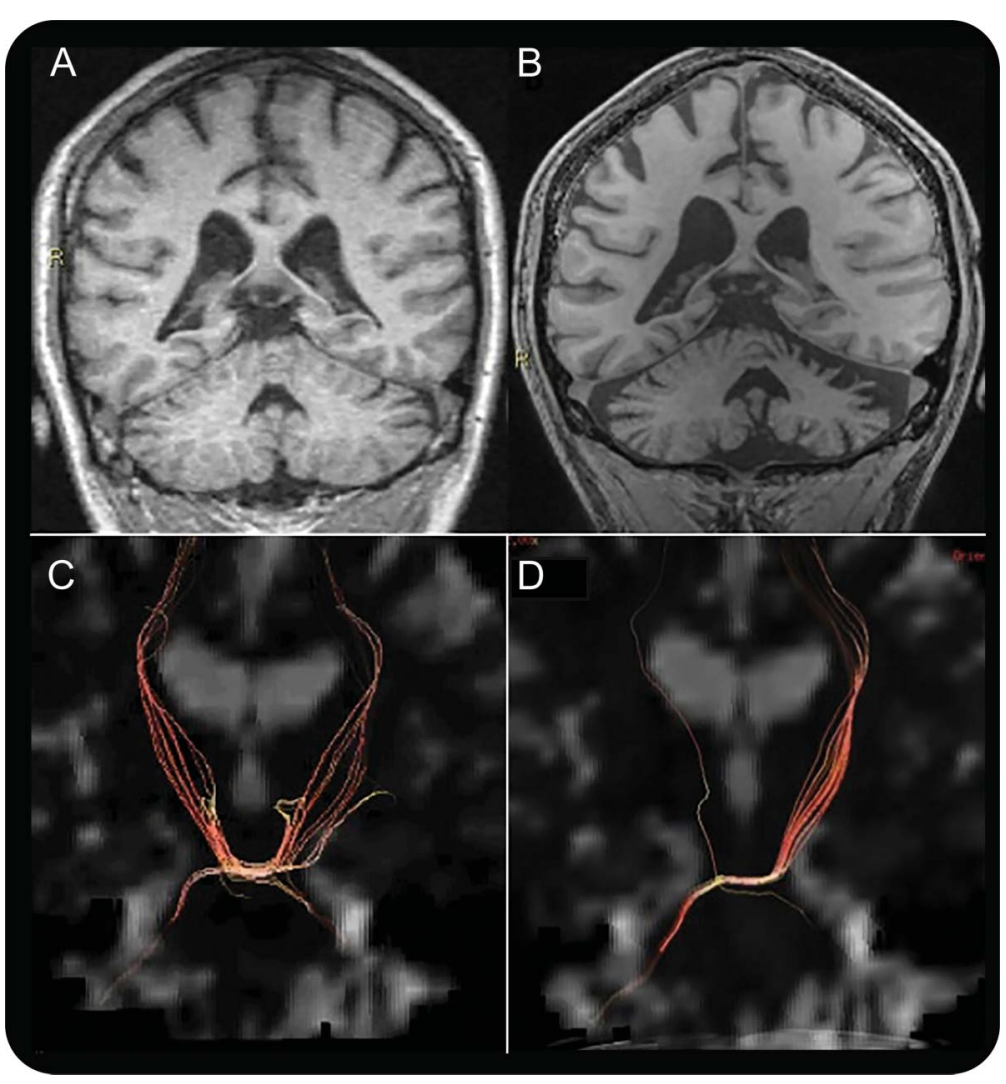

Coronal T1-weighted images performed in 2007 (A) and 2011 (B) show progressive right cerebral and left cerebellar atrophy consistent with crossed cerebellar diaschisis. Right cortico-ponto-cerebellar axonal loss was demonstrated by specific diffusion tensor imaging software for tractography in 2011 (D) as compared to 2007 (C). 


\section{Neurology}

\section{Teaching NeuroImages: Diffusion tensor tractography of cortico-ponto-cerebellar pathways in Rasmussen encephalitis}

Roberto Michelucci, Elena Pasini, Federica Anna Marliani, et al.

Neurology 2015;85;e15-e16

DOI 10.1212/WNL.0000000000001733

This information is current as of July 13, 2015

\section{Updated Information \& \\ Services}

Supplementary Material

\section{References}

Subspecialty Collections

Permissions \& Licensing

Reprints including high resolution figures, can be found at:

http://n.neurology.org/content/85/2/e15.full

Supplementary material can be found at:

http://n.neurology.org/content/suppl/2015/07/11/WNL.0000000000001 733.DC1

This article cites 2 articles, 0 of which you can access for free at: http://n.neurology.org/content/85/2/e15.full\#ref-list-1

This article, along with others on similar topics, appears in the following collection(s):

\section{DWI}

http://n.neurology.org/cgi/collection/dwi

Encephalitis

http://n.neurology.org/cgi/collection/encephalitis

MRI

http://n.neurology.org/cgi/collection/mri

Prognosis

http://n.neurology.org/cgi/collection/prognosis

Status epilepticus

http://n.neurology.org/cgi/collection/status_epilepticus

Information about reproducing this article in parts (figures,tables) or in its entirety can be found online at:

http://www.neurology.org/about/about_the_journal\#permissions

Information about ordering reprints can be found online:

http://n.neurology.org/subscribers/advertise

Neurology ${ }^{\circledR}$ is the official journal of the American Academy of Neurology. Published continuously since 1951, it is now a weekly with 48 issues per year. Copyright @ 2015 American Academy of Neurology. All rights reserved. Print ISSN: 0028-3878. Online ISSN: 1526-632X.

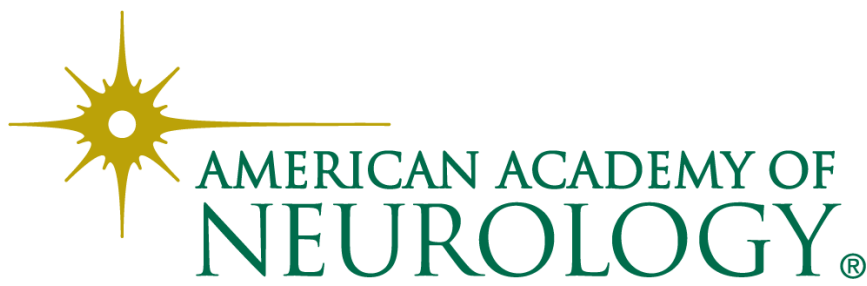

